\title{
Assessment of the levels of polychlorinated biphenyls in sediments of new Calabar River, Niger Delta Region, Nigeria
}

\author{
Ifenna ILECHUKWU, ${ }^{1 *}$ Nkoli M. MGBEMENA, ${ }^{2}$ Patience O. INAGBOR,,${ }^{1}$ and Gloria I. NDUKWE ${ }^{3}$ \\ ${ }^{I}$ Department of Industrial Chemistry, Madonna University, Elele, Rivers State Nigeria \\ ${ }^{2}$ Department of Industrial Chemistry, Michael Okpara University of Agriculture, Umudike, Abia State, Nigeria \\ ${ }^{3}$ Department of Chemistry, Rivers State University, Nkpolu-Oroworukwo, Port Harcourt, Rivers State, Nigeria
}

\begin{abstract}
The concentrations of polychlorinated biphenyls (PCBs) in sediment samples from the New Calabar River in the Niger Delta Region of Nigeria were determined. Grab sediment samples were collected from five stations in the river and analyzed for individual PCB congeners using gas chromatography - mass spectrometer. The $\sum_{8} \mathrm{PCB}$ (sum of eight congeners) identified in the samples ranged from 0.21 to $2.16 \mathrm{mg} / \mathrm{kg}$. Congener 105 and 194 were the most and least abundant with $34.65 \%$ and $2.46 \%$ respectively. The lower chlorinated congeners (below PCB 101) were prominent with $54.68 \%$ of the total PCBs concentration in the sediments. The results of this study should make PCBs contaminants of grave concern in the Niger Delta Region.
\end{abstract}

Keywords: sediments, New Calabar River, Niger Delta, polychlorinated biphenyls, congener.

\section{Introduction}

Polychlorinated biphenyls (PCBs) are persistent organic pollutants with significant bioaccumulation potentials in environmental systems. They are a worrisome group of persistent organic pollutants (POPs) due to their specific characteristics such as low degradation rates in the environment, potential toxicity to organisms and the capacity for bioaccumulation. Some of the most known POPs are the PCBs, which are a class of 209 congeners, each of which consists of two benzene rings and one to ten chlorine atoms [1]. They are synthetic compounds, used as coolants and insulating fluids in the production of transformers and capacitors. They are also used as hydraulic fluids, plasticizers, additives in paints, adhesives, lubricants, plastics, and pesticides [2-4].

Exposure to PCBs has been linked to cancer, cardiovascular disease and neuropsychological malfunction in children, reproductive impairments and endocrine disruption [5-8]. The level of toxicity exhibited by each PCB congener is a function of the pattern of chlorine substitution [9]. Environmental occurrence of persistent organic pollutants is a global problem. They are produced and temporarily washed down the aquatic environment over time where they subsequently end up in ports, estuarine and coastal sediments including in regions where they have never been used or produced [10, 11]. Although the production, usage and disposal of PCBs have been regulated or prohibited in most developed countries, PCBs are still used in many developing countries.
Sources into the marine environment include destruction and disposal of industrial plants and equipment or from emissions and leakages from construction materials and old electrical equipment $[12,13]$.

The New Calabar River is among the important water resources in the Niger Delta region of Nigeria. It is a significant water source for agricultural, recreational and domestic purposes. The river is also subjected to municipal runoffs and effluent discharges from industries including from oil and gas related activities in the region; yet only a few environmental studies have been conducted on PCBs in the Niger Delta due to much focus on petroleum hydrocarbons [14-16]. This is not surprising as the region suffers from perennial environmental negligence resulting from drilling, production and refining of crude oil as well as industrial use of petroleum products [17-20]. Hence, the aim of this study is to determine the levels of concentration of PCBs in sediment samples from New Calabar River in the Niger Delta region of Nigeria.

\section{Experimental}

\subsection{Study area}

The entire New Calabar river course is situated between longitude $7^{\circ} 60^{\prime} \mathrm{E}$ and latitude $5^{\circ} 45^{\prime} \mathrm{N}$ in the coastal area of the Niger Delta and empties into the Atlantic Ocean. The river is subjected to municipal runoffs and effluent discharges from industries including discharges from crude oil exploration. There are markets, slaughter houses, municipal waste

\footnotetext{
* Corresponding author. E-mail address: iilechukwu@ madonnauniversity.edu.ng (Ifenna Ilechukwu)
} 
disposal and incineration points along the banks of the river. Dredging, fishing and recreational activities also occur in the river. The river once served as a ship construction yard and is presently littered with abandoned ships and boats.

\subsection{Sample collection}

Sediment samples were collected from five different stations using a Van-Veen grab sampler. At each station, samples were collected from three points across the river and then thoroughly mixed to form a composite sample. The samples were packed in ice boxes and stored at $4{ }^{\circ} \mathrm{C}$ until analysis. Samples were air-dried at ambient temperature, ground with porcelain mortar and pestle and passed through 0.5 mm sieve.

\subsection{Extraction}

Sediment samples $(2 \mathrm{~g})$ were separately weighed into glass bottles and $20 \mathrm{ml}$ hexane was added to each glass bottle for extraction. Glass bottles with contents were placed in an ultrasonic shaker for 1 hour. The process was repeated twice; after which the extracts were pooled and concentrated to $2 \mathrm{ml}$ using a rotary evaporator. Clean up of extracts was done using column chromatography. Packing of the column was done using the slurry method and silica gel (130-270 mesh) as stationary phase.

Table 1. GPS coordinates of the sampling stations.

\begin{tabular}{cl}
\hline \multicolumn{1}{c}{ Samples } & \multicolumn{1}{c}{ Coordinates } \\
\hline Sample A & Latitude: 4.8872 \\
& Longitude: 6.8924 \\
Sample B & Latitude: 4.8921 \\
& Longitude: 6.8988 \\
Sample C & Latitude: 4.8842 \\
& Longitude: 6.8936 \\
Sample D & Latitude: 4.8892 \\
& Longitude: 6.8985 \\
Sample E & Latitude: 4.8979 \\
& Longitude: 6.8999 \\
\hline
\end{tabular}

The concentrated extract was introduced into an already packed $15 \mathrm{~cm} \times 1 \mathrm{~cm}$ glass column and eluted with $30 \mathrm{ml}$ dichloromethane (DCM) to obtain the fraction containing the PCBs. The fractions were concentrated to $2 \mathrm{ml}$ using a rotary evaporator and then analyzed using gas chromatography - mass spectrometer (GC-MS). Concentrations of PCBs in the fractions were monitored with Agilent 7820A gas chromatograph equipped with Agilent 5975 series mass spectrometer detector (MSD). A fused - silica capillary column $(30 \mathrm{~m} \times 0.25 \mathrm{~mm} \times 0.25 \mu \mathrm{m})$ was used for the quantification. The oven temperature was programmed from an initial temperature of $50{ }^{\circ} \mathrm{C}(1$ min) to $290{ }^{\circ} \mathrm{C}$ at the rate of $10{ }^{\circ} \mathrm{C} \mathrm{min}^{-1}$ and was maintained at $290{ }^{\circ} \mathrm{C}$ for $20 \mathrm{~min}$. Helium was used as the carrier gas. PCBs concentrations were determined through comparison of the retention times of the chromatographic peaks of the samples to the external standard solution. Compound identification was confirmed with the MSD in SIM mode (scan range 40 - $350 \mathrm{amu}$ ). Concentrations of individually resolved peaks were summed to obtain the total PCBs concentration in each sampling station.

\subsection{Quality Control}

The quality control procedures included the analysis of the reference materials and procedural blanks. The results of the reference materials were within the certified range for the representative PCBs.

\section{Results and discussion}

The analyzed sediment samples from the New Calabar River showed the presence of eight PCB congeners: 2-chlorobiphenyl (PCB 1), 2,3dichlorobiphenyl (PCB 5), 2,2',5 - trichlorobiphenyl (PCB 18), 3,3',4,4' - tetrachlorobiphenyl (PCB 77), $2,3,3^{\prime}, 4,4^{\prime}$ - pentachlorobiphenyl (PCB 105), $2,3,3^{\prime}, 4,4^{\prime}, 5$ - hexachlorobiphenyl (PCB 156), $2,3,3$ '4,4'5,5' - heptachlorobiphenyl (PCB 189) and 2,2',3,3',4,4',5,5' - octachlorobiphenyl (PCB 194) (Table 2) [21]. The total PCBs obtained from all sampling stations were higher than the recommended sediment quality guidelines for the protection of aquatic life [22]. They were also higher than results obtained from similar studies of different locations in the Niger Delta Region [14-16]. The $\sum_{8} \mathrm{PCB}$ concentration ranged from 0.21 to $2.16 \mathrm{mg} / \mathrm{kg}$. Congener 105 and 194 were the most and least abundant with $34.65 \%$ and $2.46 \%$ respectively (Figure 1).

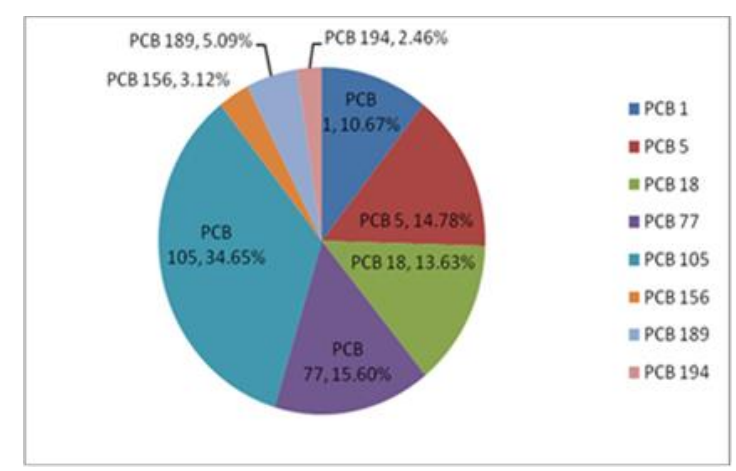

Figure 1. Percentage contribution of each congener to the total PCBs in the sediments.

The lower chlorinated congeners (below PCB 101) represented $54.68 \%$ of the total PCBs concentration in the sediments. The dominance of lower chlorinated congeners suggests that there are no significant local sources of the PCBs. This may be because lower chlorinated PCBs are usually transported to a further distance from the source than the highly chlorinated PCBs [23]. It may also be as a result of depletion of the higher chlorinated congeners $[11,24]$. It is important to note that congeners 105 , 156 , and 189 identified in these samples are among 
the most toxic PCB congeners known as the dioxinlike PCBs (DL-PCBs) [25]. The presence of PCBs in the sediments of the New Calabar River may be due to wastes dump as well as the industrial and shipping activities within the vicinities of the river. PCB 105 , which is the most prominent $\mathrm{PCB}$ congener in this study has been implicated as a derivative of paint additives [26]. Other PCB sources include incinerators, indiscriminate disposal of solid and liquid waste, industrial discharge, human faeces and runoffs from market $[9,13]$.

Table 2. PCB concentration in the sediments of New Calabar River.

\begin{tabular}{l|c|cccccc}
\hline \multirow{2}{*}{ PCBs } & \multirow{2}{*}{$\begin{array}{c}\text { Mass to } \\
\text { charge ratio }\end{array}$} & \multicolumn{7}{c}{ PCBs concentration (mg/kg) } \\
\cline { 3 - 8 } & & $\mathbf{A}$ & $\mathbf{B}$ & $\mathbf{C}$ & $\mathbf{D}$ & $\mathbf{E}$ & $\sum$ PCBs \\
\hline PCB 1 & 188 & 0.01 & 0.11 & 0.21 & 0.21 & 0.11 & 0.65 \\
PCB 5 & 222 & 0.08 & 0.12 & 0.20 & 0.28 & 0.22 & 0.90 \\
PCB 18 & 256 & 0.05 & 0.05 & 0.23 & 0.25 & 0.25 & 0.83 \\
PCB 77 & 292 & 0.07 & 0.07 & 0.27 & 0.27 & 0.27 & 0.95 \\
PCB 105 & 326 & ND & 0.01 & 1.00 & 0.10 & 1.00 & 2.11 \\
PCB 156 & 360 & ND & 0.01 & ND & 0.10 & 0.08 & 0.19 \\
PCB 189 & 394 & ND & 0.02 & 0.01 & 0.09 & 0.19 & 0.31 \\
PCB 194 & 428 & ND & 0.01 & 0.09 & 0.01 & 0.04 & 0.15 \\
$\sum$ 8PCB & & $\mathbf{0 . 2 1}$ & $\mathbf{0 . 4 0}$ & $\mathbf{2 . 0 1}$ & $\mathbf{1 . 3 1}$ & $\mathbf{2 . 1 6}$ & $\mathbf{6 . 0 9}$ \\
\hline
\end{tabular}

ND: Not detected

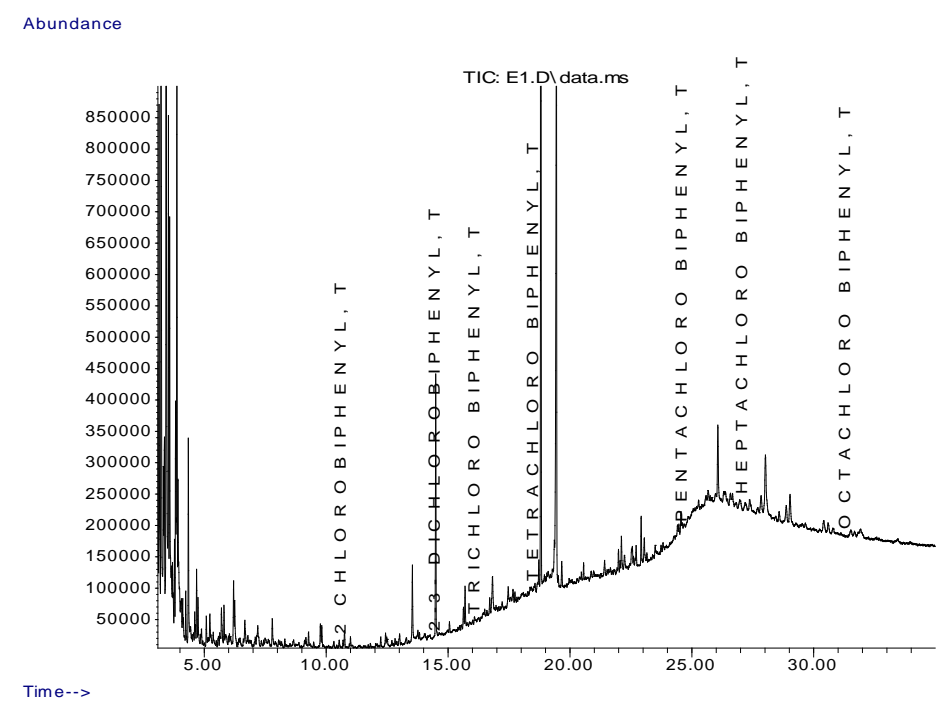

Figure 2. Chromatogram of sample E.

\section{Conclusion}

The sediments of New Calabar River in the Niger Delta Region of Nigeria were contaminated by polychlorinated biphenyls (PCBs). While PCB 105 was the most prominent congener, the lower chlorinated congeners (below PCB 101) represented $54.68 \%$ of the total PCB concentration in the sediment. This study provides results that can be used as a reference regarding PCBs levels in New Calabar River and by extension, the Niger Delta region. It underscores the significance of increasing anthropogenic activities in the region besides oil and gas as well as the need to extend environmental monitoring to pollutants other than petroleum hydrocarbons.

\section{Conflict of interest}

The authors declare that there is no conflict of interest regarding this research article.

\section{References}

[1]. O. Hutzinger, S. Safe, V. Zitko, The Chemistry of PCBs. CRC Press, Boca Raton, FL, 1974.

[2]. F. Anna, Determining the PCBs in fish and sediment samples related to intercomparison studies, Polish Journal of Environmental Studies 22 (2013) 1341-1347.

[3]. A.R. Schneider, H.M. Stapleton, J. Cornwell, J.E. Baker, Recent declines in PAH, PCB and toxaphene levels in the Northern Great Lakes as determined from high resolution sediment cores, 
Environmental Science and Technology 35 (2001) 3809-3815.

[4]. B. Strandberg, C. Bandh, B. Bavel, A. Bergqvist, D. Broman, R. Ishag, C. Naf, C. Rappe, Organochlorine compounds in the Gulf of Bothnia, sediment and benthic species, Chemosphere 40 (2000) 1205-1211.

[5]. M.H. Ward, J.S. Colt, C. Metayer, R.B. Gunier, J. Lubin, V. Crouse, M.G. Nishioka, P. Reynolds, P.A. Buffler, Residential exposure to polychlorinated biphenyls and organochlorine pesticides and risk of childhood leukemia, Environmental Health Perspectives 117 (2009) 1007-1013. Doi: 10.1289/ehp.0900583

[6]. A. Goncharov, R.F. Haase, A. Santiago-Rivera, G. Morse, R.J. McCaffrey, R. Rej, D.O. Carpenter, High serum PCBs are associated with elevation of serum lipids and cardiovascular disease in a naïve American population, Environmental Research 106 (2008) 226-239.

[7]. S.L. Schantz, J.J. Widholm, D.C. Rice, Effects of PCB exposure on neuropsychological function in children, Environmental health Perspectives 111 (2003) 357-376.

[8]. T. Colborn, M.J. Smolen, Epidemiological analysis of persistent organochlorine contaminants in cetaceans, Reviews of Environmental Contamination and Toxicology 146 (1996) $91-172$.

[9]. N.U. Benson, O.H Fred-Ahmadu, A.E. Adedapo, W.U. Anake, Characterisation of polychlorinated biphenyls in coastal inland seawater, Nigeria, Earth and Environmental Science 68 (2017) 012007

[10]. T. Combi, C.C. Martins, S. Taniguchi, J. Leonel, R. A. Lourenco, R. C. Montone, Depositional history and inventories of polychlorinated biphenyls (PCBs) in sediment cores from an Antarctic Specially Managed Area (Admiralty Bay, King George Island), Marine Pollution Bulletin 118 (2017) 447 - 451. Doi: 10.1016/j.marpolbul.2017.03.031

[11]. A. El Nemr, A.A. Moneer, A. Khaled, A. ElSikaily, Contamination and risk assessment of organochlorines in surface sediments of Egyptian Mediterranean coast, Egyptian Journal of Aquatic Research 38 (2012) 7-21.

[12]. M. Kohler, J. Tremp, M. Zennegg, C. Seiler, S. Minder-Kohler, M. Beck, P. Lienemann, L. Wegmann, P. Schmi, Joint sealants: an overlooked diffuse source of polychlorinated biphenyls in buildings, Environmental Science and Technology 39 (2005) 1967-1973.

[13]. A.O. Barakat, M. Kim, Y. Qian, T.L. Wade, Organochlorine pesticides and PCB residues in sediments of Alexandria harbor, Egypt, Marine Pollution Bulletin 44 (2002) 1421-1434.

[14]. O. Edjere, O. Iyekowa, Assessment of the levels of polychlorinated biphenyls (PCBs) in
Orogodo River sediments Agbor, Delta State, Nigeria, Ovidius University Annals of Chemistry 28 (2017) 25-29. Doi: 10.1515/auoc2017-0005

[15]. E.O. Fagbote, E.O. Olanipekun, Levels of polycyclic aromatic hydrocarbons and polychlorinated biphenyls in sediment of bitumen deposit impacted area, International Journal of Environmental Science and Technology 7 (2010) 561-570.

[16]. L.I.N. Ezemonye, Polychlorinated biphenyls $(\mathrm{PCBs})$ levels and distribution in Ethiope and Benin Rivers of the Niger Delta, Nigeria: surface water and sediments, International Journal of Environmental Studies 62 (2007) 491-504.

[17]. I. Ilechukwu, L.C. Osuji, M.O. Onyema, G.I. Ndukwe, Occurrence and sources of aliphatic hydrocarbons in soils within the vicinity of hot mix asphalt plants in Obigbo and Igwuruta areas of Rivers State, Nigeria, Journal of Applied Science and Environmental Management 20 (2016) 1087 - 1094.

[18]. L.C. Osuji, I.P. Ilechukwu, M.O. Onyema, Distribution and sources of aliphatic hydrocarbons (AHCs) and polycyclic aromatic hydrocarbons (PAHs) within the vicinity of a hot mix asphalt (HMA) plant in Port Harcourt, Nigeria, International Journal of Environmental Sciences 3 (2012) 697 - 706.

[19]. L.C. Osuji, O. Achugasim, Environmental degradation of polluting aromatic and aliphatic hydrocarbons; a case study, Chemistry and Biodiversity 4 (2007) 424 - 430.

[20]. C.A. Anyakora, K.A. Ogbeche, P. Palmer, H. Coker, G. Ukpo, C. Ogah, GC/MS analysis of polynuclear aromatic hydrocarbons in sediment samples from the Niger Delta Region, Chemosphere 60 (2005) 990 - 997. Doi: 10.1016/j.chemosphere.2004.12.073

[21]. S.A. Mills III, D.I. Thai, J. Barney, A summary of the 209 PCB congener nomenclature, Chemosphere 68 (2007) 1603 - 1612. Doi: 10.1016/j.chemosphere.2007.03.052

[22]. Canadian Council of Ministers of Environment, Sediment quality guidelines for the protection of aquatic life (2001).

[23]. D.M.S. Aly Salem, A. Khaled, A. El Nemr, Assessment of pesticides and polychlorinated biphenyls (PCBs) in sediments of the Egyptian Mediterranean Coast, Egyptian Journal of Aquatic Research 39 (2013) 141-152. Doi: 10.1016/j.ejar.2013.11.001

[24]. I. Tolosa, J.M. Bayona, J. Albaiges, Spatial and temporal distribution, fluxes, and budgets of organochlorinated compounds in Northwest Mediterranean sediments, Environmental Science and Technology 29 (1995) 2519-2527.

[25]. L. Webster, P. Roose, B. Bersuder, M. Kotterman, M. Haarich, K. Vorkamp, 
Determination of polychlorinated biphenyls (PCBs) in sediment and biota, ICES Techniques in Marine Environmental Sciences No. 53 (2013).

[26]. T. Yao, C. He, P. Zhang, H. Gao, C. Zhou, Distribution and sources of chlorinated biphenyls (PCBs) and organochlorine pesticides (OCPs) in surface waters of Jinzhou Bay in
China, Procedia Environmental Sciences 18

(2013) $317 \quad$ - $322 . \quad$ Doi:

10.1016/j.proenv.2013.04.041

Received: 14.04 .2018

Received in revised form: 10.06.2018

Accepted: 11.06.2018 